\title{
KERAGAMAN MAKAN MINIMUM SEBAGAI FAKTOR DOMINAN STUNTING PADA ANAK USIA 6-23 BULAN DI KABUPATEN KUPANG
}

\author{
Irmawati Apriany Thobias ${ }^{1}$, Kusharisupeni Djokosujono ${ }^{2}$ \\ ${ }^{1}$ Pascasarjana IImu Kesehatan Masyarakat, Universitas Indonesia, Depok, \\ Jawa Barat \\ 2Departemen Gizi, Fakultas Kesehatan Masyarakat, Universitas Indonesia, \\ Depok, Jawa Barat \\ e-mail: irmathobias@gmail.com \\ DOI $10.35451 / \mathrm{jkg} \cdot \mathrm{v} 3 \mathrm{i} 2.592$
}

\begin{abstract}
Stunting in children is one of the things that most significantly hinders human development, which globally affects around 162 million children under 5 years (WHO, 2017). Kupang Regency is one of the contributors to the stunting rate with a prevalence of $46.2 \%$ in 2013 and increasing in 2019 to $50.3 \%$ (SSGBI, 2019). This study aims to determine the factors most associated with the incidence of stunting in children 6 -23 months in Kupang Regency. This study used secondary data from the results of the 2019 YASATU NGO survey with the simple random sampling method, with a sample of 166 children aged 6-23 months. The variables analyzed consisted of the dependent variable stunting, the independent variables: maternal age and education, age and sex of the child, breastfeeding status, minimum dietary diversity, minimum meal frequency, and minimum acceptable diet. The bivariate analysis showed that there hadn't a relationship between maternal age, maternal education, child age, child sex, breasfeeding status on the incidence of stunting. Meanwhile, there was a significant relationship between minimum dietary diversity (MDD), minimum meal frequency (MMF), minimum acceptable diet (MAD) on the incidence of stunting. The final result of multivariate analysis showed that minimum dietary diversity had the greatest Odds Ratio (OR=12,341; CI $95 \%=3,118-48,841)$. It was controlled by breastfeeding status, minimum meal frequency and minimum accpetable diet. Minimum dietary diversity is a dominant factor of stunting in children aged 6-23 months in Kupang Regency. Children who did not meet MDD have 12,3 times higher risk of stunting than those who meet MDD.
\end{abstract}

Keywords: stunting, minimum diversity, frequency, acceptable diet. 


\section{PENDAHULUAN}

Banyaknya kematian bayi dan anak, tidak sedikit dikarenakan kekurangan gizi pada usia dini. Menurut World Health Organization (WHO), salah satu hal yang paling signifikan menghambat perkembangan manusia yaitu stunting, stunting mempengaruhi sekitar 162 juta anak balita di dunia (WHO, 2017).

Data Riset Kesehatan Dasar (Riskesdas) Indonesia pada tahun 2018 menunjukkan prevalensi stunting sebesar $30,8 \%$ atau dapat dikatakan bahwa 1 dari 3 anak balita mengalami stunting. Data 2019 hasil riset studi status gizi balita Indonesia (SSGBI) mencatat prevalensi balita stunting di Indonesia mencapai 27,6\%. Angka tersebut masih menunjukkan masalah kesehatan masyarakat, karena melebihi standar WHO $<20 \%$. Pada tahun 2020, meskipun terjadi pandemi Covid-19, Presiden Republik Indonesia menegaskan bahwa stunting tetap menjadi prioritas nasional.

Data hasil Pantauan Status Gizi (PSG) tahun 2017, menunjukkan prevalensi stunting pada balita di Nusa Tenggara Timur (NTT) sebesar 40,3\%. Tidak berbeda jauh dengan hasil Riskesdas 2018, dimana prevalensi balita stunting di NTT menempati posisi tertinggi dibandingkan provinsi lainnya di Indonesia yakni sebesar 42,6\%. Angka ini jauh dari ambang batas WHO $(<20 \%)$, sehingga termasuk kategori prevalensi sangat tinggi atau serius dalam masalah kesehatan masyarakat.

Pola pemberian makan pada anak dimasa 1000 HPK sangat berpengaruh terhadap keoptimalan pertumbuhan anak. Praktik pemberian makan bayi dan anak yang tidak tepat menjadi etiologi masalah stunting pada anak dan sumber utama penyakit pada anak usia di bawah 2 tahun di Negara berkembang atau daerah tertinggal termasuk Nusa Tenggara Timur. Hasil temuan Survey Demografi dan Kesehatan Indonesia
(SDKI) tahun 2017 menyatakan bahwa 6 dari 10 anak atau sebesar $60 \%$ anak usia 6-23 bulan di Indonesia tidak mendapatkan praktik pemberian makanan pendamping ASI (MP-ASI) sesuai dengan rekomendasi (SDKI, 2017) atau tidak memenuhi kualitas dan kuantitas makan dimana sebesar $40 \%$ anak tidak memenuhi keragaman makan minimal, dan sebesar $28 \%$ anak tidak memenuhi frekuensi makan minimal. Provinsi NTT dengan kasus stunting paling tinggi ternyata juga memiliki prevalensi yang rendah untuk praktik pemberian makan bayi dan anak usia 6-23 bulan, dimana sebesar 73,2\% anak tidak mendapatkan MP-ASI sesuai rekomendasi. Sebesar $60,1 \%$ anak usia 6-23 bulan di NTT tidak memenuhi keragaman makan minimal dan sebesar $28,6 \%$ anak usia $6-23$ bulan tidak memenuhi frekuensi makan minimal (SDKI, 2017). Kabupaten Kupang yang merupakan salah satu Kabupaten penyumbang angka stunting dengan prevalensi sebesar $46,2 \%$ pada tahun 2013 dan meningkat pada tahun 2019 hingga 50,3\% (SSGBI, 2019) menjadi perhatian peneliti untuk melihat hubungan kausal terkait kejadian stunting dan pemberian makanan pendamping ASI (MP-ASI) pada balita usia 6-23 bulan.

\section{METODE}

Desain yang digunakan yaitu potong lintang (cross-sectional) melalui pendekatan kuantitatif. Penelitian dilakukan di Wilayah Kabupaten Kupang, Provinsi Nusa Tenggara Timur. Data yang digunakan yaitu data sekunder yang diperoleh dari hasil survei Yayasan Satukan Aksi Tunas Utama (LSM YASATU) yang bekerja di 32 desa di Kabupaten Kupang dalam program multisektor pencegahan stunting Tahun 2019. Besar sampel dalam penelitian ini adalah total seluruh balita usia 6-23 bulan yang disurvei 
yakni sebanyak 166 balita usia 6-23 bulan.

Variabel terikat yang diteliti adalah kejadian stunting, sedangkan variabel bebas yaitu umur ibu, pendidikan ibu, umur anak, jenis kelamin dan indikator pemberian MPASI. Indikator yang dimaksud yaitu status menyusui, keragaman makan minimal atau minimum dietary diversity (MDD); frekuensi makan minimal atau minimum meal frequency (MMF), diet minimal yang diterima atau minimum acceptable diet (MAD) (WHO, 2010).

Analisis data menggunakan uji binary logistic untuk melihat hubungan antara variabel bebas dan terikat, sekaligus untuk menyeleksi variabel yang akan masuk dalam analisis multivariat. Selanjutnya uji multivariat untuk penentuan model multivariat dan juga uji interaksi.

\section{HASIL}

Tabel 1 menunjukkan bahwa dari 166 responden yang diteliti, kebanyakan responden memiliki anak dengan status normal yaitu sebanyak 113 responden $(68,1 \%)$.

Tabel 1. Distribusi Frekuensi Kejadian Stunting di Kabupaten Kupang

\begin{tabular}{lcc}
\hline \multicolumn{1}{c}{ Stunting } & Jumlah (n) & $\begin{array}{c}\text { Persentase } \\
(\%)\end{array}$ \\
\hline Stunting & 53 & 31,9 \\
Normal & 113 & 68,1 \\
Jumlah & $\mathbf{1 6 6}$ & $\mathbf{1 0 0}$ \\
\hline
\end{tabular}

Tabel 2 menunjukkan bahwa persentase stunting lebih tinggi pada kelompok umur ibu $<20$ tahun yaitu sebesar $42,9 \%$. Berdasarkan pendidikan ibu, persentase stunting lebih tinggi pada ibu yang berpendidikan SD yakni sebesar 35,6\%. Pada karakteristik anak, berdasarkan jenis kelamin anak, persentase stunting lebih tinggi pada perempuan yaitu sebanyak 33,3\%, sedangkan menurut usia persentase stunting yang lebih berisiko pada kelompok usia 12-23 bulan yaitu sebesar $34,4 \%$.
Tabel 2. Distribusi Karakteristik Responden dengan Kejadian Stunting di Kabupaten Kupang

\begin{tabular}{|c|c|c|c|c|c|c|}
\hline \multirow[t]{3}{*}{ Karakteristik } & \multicolumn{4}{|c|}{ Kejadian Stunting } & \multirow{2}{*}{\multicolumn{2}{|c|}{ Total }} \\
\hline & \multicolumn{2}{|c|}{ Stunting } & \multicolumn{2}{|c|}{ Normal } & & \\
\hline & $\mathrm{n}$ & $\%$ & $\mathrm{n}$ & $\%$ & $\mathrm{n}$ & $\%$ \\
\hline \multicolumn{7}{|c|}{ Umur Ibu } \\
\hline$<20$ tahun & 3 & 42,9 & 4 & 57,1 & 7 & 100 \\
\hline $\begin{array}{l}20-35 \\
\text { tahun }\end{array}$ & 47 & 31,5 & 102 & 68,5 & 149 & 100 \\
\hline$>35$ tahun & 3 & 30,0 & 7 & 70,0 & 10 & 100 \\
\hline \multicolumn{7}{|c|}{ Pendidikan Ibu } \\
\hline SD & 16 & 35,6 & 29 & 64,4 & 45 & 100 \\
\hline SMP & 15 & 28,3 & 38 & 71,7 & 53 & 100 \\
\hline SMA & 19 & 32,2 & 40 & 67,8 & 59 & 100 \\
\hline PT & 3 & 33,3 & 6 & 66,7 & 9 & 100 \\
\hline \multicolumn{7}{|c|}{ Umur Anak } \\
\hline 6-11 bulan & 21 & 28,8 & 52 & 71,2 & 73 & 100 \\
\hline $12-23$ bulan & 32 & 34,4 & 61 & 65,6 & 93 & 100 \\
\hline \multicolumn{7}{|c|}{ Jenis Kelamin Anak } \\
\hline Perempuan & 32 & 33,3 & 64 & 66,7 & 96 & 100 \\
\hline Laki-laki & 21 & 30,0 & 49 & 70,0 & 70 & 100 \\
\hline
\end{tabular}

Tabel 3. menunjukkan bahwa

persentase stunting lebih tinggi pada anak yang tidak lagi menyusui yaitu sebesar 39,7\% (27 balita). Berdasarkan indikator pemberian makan diperoleh bahwa anak yang mengalami stunting paling banyak berada pada kategori tidak memenuhi indikator tersebut. Anak stunting yang tidak memenuhi MMF sebesar 39,3\% (35 balita), anak stunting yang tidak memenuhi MDD yakni sebesar $48,1 \%$ (50 balita), dan anak stunting yang tidak memenuhi MAD sebesar 40,3\% (52 balita).

Tabel 3. Distribusi Frekuensi Status

Menyusui, MMF, MDD, MAD dengan Kejadian Stunting di Kabupaten Kupang

\begin{tabular}{|c|c|c|c|c|c|c|}
\hline \multirow[t]{3}{*}{ Karakteristik } & \multicolumn{4}{|c|}{ Kejadian Stunting } & \multicolumn{2}{|c|}{ Total } \\
\hline & \multicolumn{2}{|c|}{ Stunting } & \multicolumn{2}{|c|}{ Normal } & \multirow[b]{2}{*}{$\mathrm{n}$} & \multirow[b]{2}{*}{$\%$} \\
\hline & $\mathrm{n}$ & $\%$ & $\mathrm{~N}$ & $\%$ & & \\
\hline \multicolumn{7}{|c|}{ Status Menyusui } \\
\hline Tidak & 27 & 39,7 & 41 & 60,3 & 68 & 100 \\
\hline Masih & 26 & 26,5 & 72 & 73,5 & 98 & 100 \\
\hline \multicolumn{7}{|c|}{ Minimum Meal Frequency } \\
\hline Tidak & 35 & 39,3 & 54 & 60,7 & 89 & 100 \\
\hline Memenuhi & 18 & 23,4 & 59 & 76,6 & 77 & 100 \\
\hline \multicolumn{7}{|c|}{ Minimum Dietary Diversity } \\
\hline Tidak & 50 & 48,1 & 54 & 51,9 & 104 & 100 \\
\hline Memenuhi & 3 & 4,8 & 59 & 95,2 & 62 & 100 \\
\hline \multicolumn{7}{|c|}{ Minimum Acceptable Diet } \\
\hline Tidak & 52 & 40,3 & 77 & 59,7 & 104 & 100 \\
\hline Memenuhi & 1 & 2,7 & 36 & 97,3 & 62 & 100 \\
\hline
\end{tabular}

Untuk melihat hubungan antara

masing-masing variabel independen dengan variabel dependen, dilakukan 
Jurnal Kesehatan Masyarakat \& Gizi, e-ISSN: 2655-0849

Vol. 3 No.2 Edisi November 2020 - April 2021

https://ejournal.medistra.ac.id/index.php/JKG

Received: 17 Februari 2021 :: Accepted: 17 April 2021 :: Published: 30 April 2021

analisis hubungan menggunakan binary logistic. Hasil uji hubungan dapat dilihat dalam tabel berikut.

Tabel 4. Hubungan antara variabel independen dan variabel dependen

\begin{tabular}{lccc}
\hline \multicolumn{1}{c}{ Variabel } & $\begin{array}{c}p- \\
\text { value }\end{array}$ & OR & CI 95\% \\
\hline Umur ibu & 0,617 & 1,300 & $0,463-$ \\
& & & 3,655 \\
Pendidikan ibu & 0,821 & 0,959 & $0,667-$ \\
& & & 1,380 \\
Umur anak & 0,438 & 0,438 & $0,397-$ \\
& & & 1,494 \\
Jenis kelamin & 0,649 & 0,857 & $0,441-$ \\
& & & 1,666 \\
Status & 0,074 & 1,824 & $0,942-$ \\
menyusui & & & 3,532 \\
MMF & 0,027 & 2,124 & $1,079-$ \\
& & & 4,184 \\
MDD & 0,000 & 18,210 & $5,365-$ \\
& & & 61,811 \\
MAD & 0,000 & 24,312 & $3,232-$ \\
& & & 182,885 \\
\hline
\end{tabular}

Tabel 4 menunjukkan bahwa secara statistik umur ibu, pendidikan ibu, umur anak, jenis kelamin anak, dan status menyusui tidak memiliki hubungan yang signifikan dengan kejadian stunting dimana $p$-value> 0,05 . Variabel MMF memiliki nilai $\mathrm{p}=0,027<0,05$ maka dapat disimpulkan ada hubungan yang signifikan antara frekuensi makan dengan kejadian stunting. Berdasarkan analisis diperoleh pula nilai $\mathrm{OR}=2,124$, artinya anak yang tidak memenuhi MMF mempunyai peluang 2,1 kali lebih besar mengalami stunting dibanding anak yang memenuhi. Variabel MDD memiliki nilai $\mathrm{p}=0,000<0,05$ maka dapat disimpulkan ada hubungan yang signifikan antara keragaman makan dengan kejadian stunting. Berdasarkan analisis diperoleh pula nilai $\mathrm{OR}=18,210$ artinya anak yang tidak memenuhi MDD mempunyai peluang 18,2 kali lebih besar mengalami stunting dibanding anak yang memenuhi. Variabel MAD memiliki nilai $p=0,000<0,05$ maka dapat disimpulkan ada hubungan yang signifikan antara diet yang diterima dengan kejadian stunting. Berdasarkan analisis diperoleh pula nilai $\mathrm{OR}=24,312$ artinya anak yang tidak memenuhi MAD mempunyai peluang 24,3 kali lebih besar mengalami stunting dibanding anak yang memenuhi.

Hasil uji bivariat menggunakan binary logistic diperoleh 4 variabel yang memenuhi syarat untuk masuk dalam analisis multivariat yaitu status menyusui, MMF, MDD, dan MAD. Selanjutnya dilakukan analisis multivariat dan uji interaksi sehingga diperoleh model akhir multivariat.

Tabel 5. Hasil Pemodelan Akhir Multivariat

\begin{tabular}{|c|c|c|c|}
\hline Variabel & $\begin{array}{c}p- \\
\text { value }\end{array}$ & OR & CI $95 \%$ \\
\hline $\begin{array}{l}\text { Status } \\
\text { Menyusui }\end{array}$ & 0,408 & 1,415 & $\begin{array}{c}0,621- \\
3,225\end{array}$ \\
\hline MMF & 0,447 & 1,392 & $\begin{array}{c}0,593- \\
3,268\end{array}$ \\
\hline MDD & 0,000 & 12,341 & $\begin{array}{l}3,118- \\
48,841\end{array}$ \\
\hline MAD & 0,385 & 2,833 & $\begin{array}{l}0,271- \\
29,618\end{array}$ \\
\hline
\end{tabular}

multivariate menunjukkan bahwa hanya variabel minimum dietary diversity yang memiliki hubungan signifikan dengan kejadian stunting dimana $p$ value $=0,000<0,05$. Minimum dietary diversity dikontrol oleh variabel status menyusui, minimum meal frequency, dan minimum acceptable diet.

\section{PEMBAHASAN}

Dikatakan stunting apabila tinggi badan menurut umur $<-2 S D$ atau pendek dan <-3SD atau sangat pendek berdasarkan median WHO Child Growth Standard (WHO, 2010). Stunting merupakan akibat dari kekurangan gizi yang disebabkan oleh asupan gizi yang tidak memadai dalam waktu cukup lama atau disebut kronis. Hasil penelitian didapatkan bahwa balita yang mengalami stunting sebanyak 53 balita $(31,9 \%)$ dan tidak mengalami stunting sebanyak 113 balita $(68,1 \%)$ (Tabel 1$)$.

Penelitian yang dilakukan di Kabupaten Kupang melibatkan 166 anak usia 6-23 bulan dimana lebih banyak berjenis kelamin perempuan yaitu 
sebanyak 96 anak (57,8\%), sedangkan yang berjenis kelamin laki-laki sebanyak 70 anak (42,2\%) (Tabel 2). Diduga ada keterkaitan antara jenis kelamin dan status gizi, dikarenakan jenis kelamin menentukan besarnya kebutuhan gizi bagi seseorang. Dalam angka kecukupan gizi (AKG) Kementerian Kesehatan menunjukkan perbedaan kebutuhan gizi antara laki-laki dan perempuan berdasarkan umur. Hasil penelitian juga menunjukkan bahwa persentase kejadian stunting lebih besar pada kelompok responden dengan jenis kelamin perempuan yaitu sebanyak 32 anak $(33,3 \%)$ (Tabel 2$)$. Studi yang dilaksanakan di India menunjukkan bahwa perbedaan jenis kelamin berpengaruh signifikan terhadap kejadian stunting dimana anak perempuan lebih berisiko mengalami stunting (Biswas, 2010). Pada lokasi penelitian ini, perempuan lebih banyak mengalami stunting dikarenakan perbedaan pola asuh orangtua dalam memberikan makanan pada anak. Dalam konteks budaya setempat, anak laki-laki dianggap sebagai penerus dan harapan keluarga sehingga lebih diutamakan dalam segala aspek baik pendidikan, kesehatan dan gizi. Namun, hasil analisis menunjukkan nilai $p=0,649>0,05$ artinya secara statistik menunjukkan tidak ada hubungan yang signifikan antara jenis kelamin dengan kejadian stunting (Tabel 4).

Selain jenis kelamin, usia anak diduga berkaitan dengan stunting sama halnya dimana usia anak menentukan kebutuhan gizinya. Semakin tinggi usia seseorang, semakin besar pula kebutuhan gizi yang harus dipenuhi. Hasil penelitian ini menunjukkan persentase stunting terbesar ada di kelompok usia 12-23 bulan yaitu sebanyak 32 anak $(34,4 \%)$ (Tabel 2 ). Penelitian Roscha et al, 2012 mendukung hasil penelitian ini dimana diungkapkan bahwa usia anak kurang dari 12 bulan memiliki risiko stunting lebih rendah dibanding usia anak 12 bulan hingga 23 bulan (Noor, 2015). Pada penelitian ini, hasil analisis menunjukkan nilai $p=0,438>0,05$ artinya secara statistik tidak ada hubungan yang signifikan antara usia anak dengan kejadian stunting (Tabel 4).

Hasil penelitian juga menunjukkan proporsi stunting paling besar ada pada kelompok usia ibu kurang dari 20 tahun yaitu sebesar $42,9 \%$. Wanita di bawah 20 tahun secara teori masih berada dalam pertumbuhan dan perkembangan, sehingga pada saat hamil, mengharuskan ibu dan janin dalam kandungan berbagi asupan gizi untuk memenuhi kebutuhan masing. Janin seringkali menjadi korban akibat perebutan asupan gizi yang tidak adekuat. Pada penelitian ini, hasil analisis menunjukkan nilai $p=0,617>$ 0,05 artinya secara statistik tidak ada hubungan yang signifikan antara usia ibu dengan kejadian stunting (Tabel 4).

$$
\text { Tabel } 2 \text { menunjukkan }
$$

berdasarkan pendidikan ibu proporsi stunting lebih tinggi pada tingkat pendidikan sekolah dasar (SD) yaitu sebesar 35,6 \%. Jenjang pendidikan mempengaruhi proses penyerapan informasi kesehatan sehingga menciptakan pola hidup yang baik dan sehat (Picauly \& Toy, 2013). Dalam penelitian Akombi et al (2017) terungkap bahwa pendidikan ibu yang rendah cenderung mengakibatkan anak mengalami stunting. Hasil Riskesdas 2013 juga menunjukkan bahwa tingkat pendidikan orangtua mempengaruhi kejadian stunting dimana tingginya tingkat pendidikan orangtua berdampak pada semakin rendah anak lahir pendek. Pada penelitian ini, hasil analisis menunjukkan nilai $\mathrm{p}=0,821>0,05$ artinya bahwa secara statistik tidak ada hubungan yang signifikan antara 
pendidikan ibu dengan kejadian stunting (Tabel 4).

Status menyusui pada balita usia 6-23 bulan mempengaruhi penilaian terhadap terpenuhinya keragaman makan, frekuensi makan, dan diet yang diterima. Anak yang masih disusui kemungkinan memiliki tingkat keberagaman makan yang rendah $(\mathrm{JH}$ Rah et al, 2010). Pada penelitian ini, balita usia 6-23 bulan yang tidak lagi menyusui sebanyak 68 balita $(41 \%)$. Padahal kebutuhan gizi anak baduta masih besar dapat terpenuhi lewat ASI. Persentase terbesar stunting juga berada pada kelompok anak yang tidak lagi disusui yakni sebesar 39,7\% (Tabel 3). Hasil uji statistik didapatkan nilai $p$ value $=0,074>0,05$ yang berarti bahwa tidak ada hubungan yang signifikan antara status menyusui dengan kejadian stunting (Tabel 4).

Tidak adanya hubungan yang signifikan secara statistik namun secara teori berkaitan erat, dapat dikaji lebih dalam atau dapat diperbanyak sampel penelitian untuk menggambarkan keadaan sebenarnya.

MMF atau frekuensi makan minimal merupakan proporsi frekuensi makan anak usia 6-23 bulan yang disusui maupun tidak disusui menerima makan padat, semi padat, atau lunak (termasuk susu untuk anak yang tidak disusui) sesering mungkin atau lebih dari ketentuan minimal (WHO, 2010). Hasil penelitian menunjukkan anak yang memenuhi MMF sebesar 77 baduta $(46,4 \%)$, sedangkan sisanya sebesar 89 baduta $(53,6 \%)$ tidak memenuhi MMF. $\mathrm{Hal}$ ini menggambarkan rendahnya frekuensi makan baduta yang tentunya mempengaruhi ketercukupan asupan gizi. Rata-rata konsumsi baduta 6-23 bulan sebanyak 2-3 kali sehari baik yang masih menyusui maupun tidak lagi menyusui. Sedangkan persentase terbesar stunting berada pada kelompok anak yang tidak memenuhi MMF yakni sebesar 39,3\% (Tabel 3). Hasil uji statistik didapatkan nilai $\mathrm{p}$ value $=0,027$ $<0,05$ yang berarti bahwa terdapat hubungan yang signifikan antara MMF dengan kejadian stunting (Tabel 4). Baduta usia 6-23 bulan yang tidak memenuhi MMF berpeluang 2,1 kali lebih besar mengalami stunting dibandingkan dengan baduta yang memenuhi MMF (Nilai OR=2,124) (Tabel 4). Sejalan dengan penelitian di Padampur, Chitwan didapatkan bahwa risiko stunting 3,5 kali lebih tinggi pada balita yang tidak mendapatkan MMF sesuai rekomendasi (Ruwali, 2011).

MDD merupakan proporsi karagaman makan anak usia 6-23 bulan yang menerima makanan dengan ketentuan minimal 4 atau lebih jenis makanan dari 7 jenis makanan meliputi sereal/umbi-umbian, kacang-kacangan, produk susu, telur, sumber protein, sayuran dan buah-buahan yang kaya vitamin A, sayuran dan buah-buahan lainnya (WHO, 2010). Tingginya keragaman pangan merefleksikan kualitas diet yang baik dan pemenuhan Angka Kecukapan Gizi (AKG) yang baik pula. Pada penelitian ini baduta usia 623 bulan yang memenuhi MDD sesuai rekomendasi sebesar $37,3 \%$ sedangkan sisanya sebesar $62,7 \%$ tidak memenuhi atau mengkonsumsi kurang dari 4 kelompok makanan. Hal ini menunjukkan rendahnya keragaman pangan yang diberikan pada anak dan tentunya akan mempengaruhi status gizinya. Persentase terbesar stunting juga berada pada kelompok anak yang tidak memenuhi MDD yakni sebesar $48,1 \%$ (Tabel 3). Hasil uji statistik didapatkan nilai $p$ value $=0,000<0,05$ yang berarti bahwa terdapat hubungan yang signifikan antara MDD dengan kejadian stunting (Tabel 4). Baduta usia 6-23 bulan yang tidak memenuhi MDD berpeluang 18,2kali lebih besar mengalami stunting dibandingkan dengan balita yang memenuhi MDD 
sesuai rekomendasi (Nilai $\mathrm{OR}=18,210$ ) (Tabel 4). Hal ini sejalan dengan penelitan yang dilakukan di pedesaan Bangladesh yang menunjukkan bahwa keragaman makan yang tinggi erat kaitannya dengan penurunan stunting sebesar 15,2 dimana 31\% diantaranya merupakan anak-anak di bawah 2 tahun, sehingga disimpulkan bahwa rendahnya minimum dietary diversity merupakan predictor terjadinya stunting (JH Rah et al, 2010).

Pada penelitian ini MAD dikatakan terpenuhi apabila MDD dan MMF terpenuhi, dimana balita usia 6-23 bulan mengkonsumsi 4 atau lebih kelompok makanan dan menerima makanan utama minimal tergantung usia dan status menyusui. Hasil penelitian menunjukkan anak yang memenuhi MAD sebesar 62 balita $(37,3 \%)$, sedangkan sisanya sebesar 104 balita $(62,7 \%)$ tidak memenuhi MAD. Hal ini menggambarkan rendahnya kualitas penerimaan asupan gizi. Persentase terbesar stunting berada pada kelompok anak yang tidak memenuhi MAD yakni sebesar 40,3\% (Tabel 3). Hasil uji statistik didapatkan nilai $p$ value $=0,000<0,05$ yang berarti terdapat hubungan yang signifikan antara minimum acceptable diet dengan kejadian stunting (Tabel 4). Baduta usia 6-23 bulan yang tidak memenuhi MAD berpeluang 24,3 kali lebih besar mengalami stunting dibandingkan dengan baduta yang memenuhi MAD (Nilai OR=24,312) (Tabel 4). Hasil penelitian yang dipublikasikan pada $1^{\text {st }}$ International Conference on Community Health (ICCH 2019) menunjukkan bahwa anak yang mendapatkan MP-ASI yang tidak sesuai mengalami stunting lebih sebesar $31 \%$ dibanding anak yang mendapat MP-ASI dengan sesuai, yakni 19,5\% (Triana dan Haniyah, 2019).

$$
\text { Hasil seleksi bivariat }
$$

menunjukkan hanya 4 variabel yang dapat masuk dalam analisis multivariate dimana nilai $\mathrm{p}<0,25$ yakni variabel status menyusui, MMF, MDD dan MAD. Hasil akhir analisis multivariat diperoleh hasil pemodelan bahwa variabel MDD saja yang berhubungan dengan kejadian stunting (nilai p 0,000<0,05), sedangkan variabel status menyusui, MMF dan MAD sebagai variabel pengontrol. Sehingga dalam penelitian ini dapat dikatakan bahwa variabel MDD mempunyai nilai OR terbesar artinya baduta yang tidak memenuhi MDD memiliki peluang 12,3 kali lebih rentan mengalami stunting dibanding baduta yang memenuhi MDD (OR=12,341; CI $95 \%=3,118-48,841)$.

\section{SIMPULAN}

Berdasarkan analisis hubungan antar variabel independen dan dependen, variabel yang terbukti secara signifikan memiliki hubungan dengan kejadian stunting pada balita usia 6-23 bulan di Kabupaten Kupang yaitu frekuensi, keragaman dan diet yang diterima.

Hasil akhir pemodelan analisis multivariat menunjukkan bahwa keragaman makan atau minimum dietary diversity merupakan variabel yang paling berpengaruh terhadap kejadian stunting dikontrol oleh variabel status menyusui, minimum meal frequency, dan minimum acceptable diet. Balita yang tidak memenuhi minimum dietary diversity memiliki peluang 12,3 kali lebih rentan mengalami stunting dibanding balita yang memenuhi minimum dietary diversity $(\mathrm{OR}=12,341$; CI $95 \%=3,118$ 48,841). Oleh karena itu, dapat disimpulkan bahwa minimum dietary diversity merupakan faktor dominan kejadian stunting pada balita usia 6-23 bulan di Kabupaten Kupang. Informasi lebih lanjut dan jumlah sampel yang lebih banyak dibutuhkan untuk mendukung hasil penelitian ini. 


\section{UCAPAN TERIMA KASIH}

Terima kasih kepada Lembaga Swadaya Masyarakat Yayasan Satukan Aksi Tunas Utama (LSM YASATU) NTT yang telah mengijinkan penggunaan data hasil surveinya untuk diolah lebih lanjut menjadi suatu karya ilmiah. Kiranya tulisan hasil ini dapat dimanfaakan untuk pengembangan program pemberdayaan masyarakat.

\section{DAFTAR PUSTAKA}

Akombi, B. J., Agho, K. E., Hall, J. J., Merom, D., Astell-Burt, T., \& Renzaho, A. M.N. (2017). Stunting and severe stunting among children under- 5 years in Nigeria: A multilevel analysis. BMC Pediatrics, 17(1),15. Retrieved from https://doi.org/10.1186/s12887016- 0770

Biswas S., Bose K. (2010). Sex Differences In The Effect Of Birth Order And Parents' Educational Status On Stunting: A Study On Bengalee Preschool Children From Eastern India. Journal of Comparative Human Biology. Retrieved from www.elsevier.de/jchb

JH Rah., Akhter N., Semba RD., Pee S., Bloem MW, et al. (2010). Low Dietary Diversity Is A Predictor Of Child Stunting In Rural Bangladesh. European Journal of Clinical Nutrition (2010) 64, 1393-1398 \& 2010 Macmillan Publishers Limited All rights reserved 0954-3007/10

Kementerian Kesehatan RI. (2013). Laporan Hasil Riset Kesehatan Dasar Indonesia Tahun 2013. Jakarta: Kemenkes RI.

Kementerian Kesehatan RI. (2018). Laporan Hasil Riset Kesehatan Dasar Indonesia Tahun 2018. Jakarta: Kemenkes RI.

Kementerian Kesehatan RI. (2019). Studi Status Gizi Balita Terintegrasi Susenas 2020. Jakarta: Balitbangkes Kemenkes RI.

Noor, Rivani. (2015). Hubungan Indikator Pemberian Makan Pada Bayi dan Anak Umur 9-23 Bulan dan Faktor Lainnya Terhadap Kejadian Stunting di Posyandu Puskesmas
Warung Jambu Kota Bogor Tahun 2015. Tesis FKM, Universitas Indonesia. Depok.

Picauly, I., Toy, S.M. (2013). Analisis Determinan dan Pengaruh Stunting Terhadap Prestasi Belajar Anak Sekolah di Kupang dan Sumba Timur, NTT. Jurnal Gizi dan Pangan, 8(1), 55-62

Ruwali, D. (2011). Nutritional Status of Children Under Five Years of Age AND Factors Associated in Padampur VDC, Chitwan. Health Prospect, 2011. Vol.10.

Triana, N \& Haniyah, S. (2019). Relationship of Exclusive Breastfeeding, Complementary Feeding and Nutritional Intake with Stunting in Children in Karanglewas Health Center.1st International Conference on Community Health (ICCH 2019). Advances in Health Sciences Research, volume 20. Altantis Press

Unicef, WHO, World Bank. (2019). Levels and Trends in Child Malnutrition. Unicef/WHO/World Bank Group Joint Child Malnutrition Estimates. Key Findings of the 2019 edition.

WHO. (2010). Indicators for Assessing Infant and Young Child Feeding Practices Part 1 Definition. Geneva.

WHO. (2010). Indicators for Assessing Infant and Young Child Feeding Practices Part 2 Measurement. Geneva.

WHO. (2017). WHO Global Database on Child Growth and Malnutrition. Geneva. www.who.int. 